\title{
Melancholy and separation in prepuberty: the choice of anorexia nervosa as a subjectivation attempt
}

\author{
Manon Rivière ${ }^{1 *}$ and Marion Haza ${ }^{2}$
}

\begin{abstract}
Background: This article considers the question of the subjective elaboration of a subject's relationship to the family-other within a hospitalization facility. Our starting point is the therapeutic follow-up of Clementine, a melancholic adolescent, thrown into an institutional setting following a severe case of anorexia nervosa. We posit that, in the case of Clementine, the choice of the anorexic symptom may demonstrate both a necessity to detach herself from love objects and a difficulty in doing so, but also provides the start of a subjectifying solution.

Case presentation: We propose a qualitative method for the analysis of the individual interviews conducted with this young patient in a patient/psychologist/researcher configuration. A psychoanalytical approach sheds light on several topics: anorexia nervosa, melancholy, twinning, puberty and subjective elaboration. We present the changes in the psychological dynamics and discourse of the young girl during psychological interviews, but also in the wider framework of hospitalization (medical follow-up, family interviews, relationships to the peer group and to the healthcare team, etc.).

Conclusion: We think of the anorexic symptom more as a way of setting up the subjectivation process than as a self-destructive behavior, which enables us to address the specific features of a possible therapeutic approach. We open the debate on the question of the benefits of separation from the family and of hospitalization, as well as on the potential impact of the therapeutic framework on the symptom.
\end{abstract}

Keywords: Anorexia, Melancholy, Twinning, Hospitalization, Subjectivation

\section{Introduction}

Meeting clementine and presentation of the therapeutical environment

Clementine is a young girl who has just turned thirteen when she is admitted to a child psychiatry unit for "anorexia nervosa with melancholy". Upon her admission, she presents signs of psychical distress and her body is in an alarming state, with a BMI of 12.5. Given the extent of her undernutrition, she has not yet entered puberty when admitted to the care unit.

When she arrives there, the therapeutic framework comprises two elements. First, there is medical and

\footnotetext{
* Correspondence: manonriv@hotmail.com

'Maison des Sciences de l'Homme et de la Société, 5, Rue Théodore Lefebvre (Bât. A5), 86000 Poitiers, France

Full list of author information is available at the end of the article
}

therapeutic follow-up with a child psychiatrist, for which Clementine attends individual interviews each week. Monthly family interviews are also proposed. The second element is long-term therapeutic follow-up with a psychologist, together with an observation process by a clinical psychologist/researcher, within the framework of research work on anorexia nervosa.

As is the case for all adolescents, the young girl also attends the patients/nursing staff group, which meets weekly and is made up of different members of the nursing staff (child psychiatrists, interns, psychologists, nurses, nursing auxiliaries, etc.) as well as all the adolescents in the unit. The structure of the care unit allows Clementine to have daily contact with other young people during freer times, like meals, or in more formal settings, such as therapeutic activity groups. 
Clementine is a young girl brought up in a rural area. Her father is a self-employed farmer and her mother helps him out at the farm. The couple live with their two daughters in the family property, which belonged to the mother's parents, in the same village as the father's parents. Clementine is born thirteen months after her older sister Floriane, a restless baby who worries her mother a lot. The parental couple has difficulty handling this second pregnancy, which comes too soon after the first. It is experienced through a very fragile psychical holding described by Clementine's mother as: "a forgotten pregnancy." After her birth, Clementine's parents remain very busy with Floriane, who is described as a difficult baby, unlike her younger sister, who seems to have a capacity to "make herself forgotten." Throughout her early childhood, Clementine develops by finding a mirrored narcissistic shoring in her relationship with her sister; Clementine is ten-years-old when her sister begins secondary school, and she finds herself alone in primary school. When listening to her talk, what stands out more than anything is a psychical distress that is mainly linked to this separation. During this period, Floriane grows closer to her mother, the latter being described by Clementine as reliving her own adolescence through her firstborn. In a second phase, it appears that Clementine's melancholic state simultaneously originates from the hospitalization of her mother following a stroke, which disrupts the whole family dynamic. The presence of Clementine's father, who is mentioned very sporadically in the young girl's speech, doesn't seem to be sufficient to give her an emotional shoring, or even to act as a separator in the relationship between Floriane and her mother. Clementine initially shows a real uneasiness, before beginning a period of draconian dietary restrictions. This will lead her, at the age of eleven, to a nine-month hospitalization in the pediatrics unit. During this time, the parents show a neglectful attitude towards their daughter, increasingly spacing out their visits, to the point where they only show up when the nursing team ask them to. Consequently, when discharged, Clementine is placed in a foster family, but, after further weight loss and degradation of her bodily state, she is quickly admitted to the adolescent hospitalization unit.

At the beginning of her hospitalization, Clementine displays a very melancholic state, with no elaboration work yet in progress; she also shows considerable narcissistic devaluation and a total inability to consider the future in any way, seemingly related to some kind of inefficiency, interpersonal mistrust and a lack of interoceptive awareness [1].

We posit that, in the case of Clementine, the choice of the anorexia symptom may demonstrate both a necessity to detach herself from love objects and a difficulty in doing so, but also represents the beginning of a subjectifying solution.

\section{Changes to the family dynamics and psychological repositioning of the parent figures Early mourning of the mother figure and the place of the child}

At first, when Clementine talks about her parents, she lumps them together in their parental alliance. It is not until much later, during the follow-up, that the ambivalence of her relationship to her mother surfaces. Clementine talks about the beginning of her uneasiness: "There are memories that keep coming back to me. I see myself at the beginning of my illness, when I was crying and my mother didn't know what to do and she left". Her distress does not bring mother and daughter closer together, but rather causes them to repeat their early deficient and neglectful interactions, during which Clementine had to fend for herself, with no mother holding $^{\mathrm{a}}$ [2]. When she talks for the first time about her mother's stroke, she explains that it didn't leave any physical after-effects, but nevertheless transformed her. Crying, the young girl explains the fear she felt at that time: "She could have forgotten me". This anxiety may be understood as a repetition of the affects related to her mother's minimal investment in her pregnancy and the minimal relationship between mother and daughter during the first years of her life. The maternal change observed by Clementine is seen as a real regression from her mother, with a significant revival of the issues of her childhood and/or adolescence - "especially since Floriane went to secondary school. It was as if she was going through it all again herself!". According to [3], "it is commonly accepted that the adolescence of a child reactivates the adolescence of the parents and revives the conditions in which the latter were confronted with the physical and psychical reworking inherent [in adolescence]. This period is ripe for intense confusion, violent excitement, rivalries and incestuous confrontation". This identification mechanism between the mother and the eldest daughter can be explained by the severity of the mother's medical illness and occurs as an unconscious struggle against the idea of death by relating to a period of adolescence. Once again, Clementine feels abandoned in her child position, not secured by a "good-enough

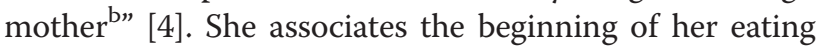
disorders with this event: "I began to stop eating after my mother's stroke, when it seemed to me that whatever I said meant nothing". Thus, in response to her speech being blocked, she ceases to use her mouth in its function as a receptacle for food. Recalcati [5], reminds us that "anorexia is not an eating disorder, but a position of the subject, i.e. a choice of the subject". The benefit of this anorexic "choice" appears when Clementine mentions the consequences of her symptom: "Before I was sick, my mother was always with my sister, and then Floriane reproached me for getting all that she wanted, 
because my mother brought me books or clothes when she came to the hospital". Clementine therefore seems only to exist for her mother as a sick, fragile child. This motherly care does not calm all her resentment, however: "I was mad at her because, even though she had no aftereffects, with me she was different [...]. It wasn't the same: afterwards, she took care of me, but it was different... It was like another kind of attachment, another relationship". Clementine experiences this change in her mother's attitude as a loss: her mother is still there- - strictly speaking, there is no mourning - and nevertheless she is not the same anymore and will probably never be the same again. The young girl knows "probably who [she] lost, but not what [she] lost in this person" [6]. Thus, the hope that Clementine may someday find in this deficient mother the image of a "good enough mother" may disappear for good. What is happening here is the mourning of the desire for an ideal, the mourning of the motherly haven [7], with all the violence and anger that entails. Faced with the trial of reality, bereavement and separation seem imminent and Clementine wavers between identifying with her mother and ambivalent feelings combining shame and fear of losing love. "I was ashamed of her after her stroke, but I don't know what she thinks about me. Maybe she's ashamed of me too but doesn't tell me". Her feelings of nonentity and rejection of life are then transferred and projected into a discourse full of anger and contempt towards her mother: "It seems she has no goal, that she isn't interested in anything", The object of motherly love, now a vehicle for the projection of her self-reproaches, shifts for Clementine from "complaints" to "plaints against" [6]. This movement creates a first gap, enabling the young girl to differentiate herself: "I don't see the point in living like this". Thus turning against herself the revival of her matricidal fantasies, the anorexic choice serves as a psychic economy for an actual suicide attempt. It is more tolerable for Clementine to attack herself directly, physically, through anorexia than to withstand with her murderous desires.

\section{Place of the father and benefits of the prepubertal symptom}

Clementine's father is described as a rather rough man, who is not really capable of expressing his feelings for his daughter. He comes to visit her only twice during the first four months of her hospitalization. Clementine speaks little about him and, when she does, it is in a less ambivalent way than when she talks about her mother and sister. When talking about him for the first time, she explains: "I have the feeling that, since the beginning, my father may be the one who has changed the least". This father, who seems to be invested with much less emotion than the mother in Clementine's discourse, serves here as a fixed point of reference, unchanged, whereas all the relationships surrounding Clementine are changing or unravelling. Moreover, it is worth noting that it is from this moment on that Clementine moves on from a discourse centered on her sister and "people" to begin to really elaborate on her family dynamics, especially her relationship to her mother. Referring to the stroke, Clementine explains: "At the end, when I was still at home, it was like my parents were not a couple anymore... It was as if me, my sister and my mother were the three daughters of my father". For Gutton [8], the pubertal revives oedipal conflict at adolescence, and the traumatic potential lies in the possibility of the adolescent realising his/her oedipal wishes, but also in what he calls "the pubertal child of the parents,", in other words, when "the adolescent secretly knows that his oedipal representations (incestuous and parricidal) have their counterparts in his parents". Clementine experiences the change in her mother's attitude as a shift in filiation, where roles and places are swapped: the mother becomes the sister and the wife becomes the daughter, thus bypassing the oedipal triangulation, eliminating generations on the female side and abrading to some extent the issues of rivalry with the parent of the same sex. This new configuration seems to take on a traumatic fantasmatic character for Clementine: if the mother is no longer perceived as the father's wife, i.e. as a rival, that leaves a vacant place to be filled, underlain with incestuous and matricidal fantasies. At the dawn of puberty, then, the rivalry seems much more significant between the two sisters than with regard to their mother. In order to ward off this huge identificatory dimension of her future pubescent body, a body ready to realize the oedipal promise ${ }^{c}$, anorexia immediately offers "an idealized body, purified, empty, cleared from all marks of the mother's legacy and distanced from the father's seduction, a body as much despised as it is idolized, and a body that would fantasmatically suitable for procreation" [9]. The girl's hunger and the slimming down of her body would provide direct proof of her successful distancing of her love objects and whatever threat they may hold. Clementine cannot distance herself from the power of this relationship with her mother [10]. Just like the Lisbon sisters in Virgin Suicides, this "pubertal overflow [...] initiates an insurmountable psychical conflict for these young girls, who prefer to erase their body, their flesh" ([11], p 112). The anorexia nervosa therefore serves to maintain Clementine in a child's body, whereas her sister is transforming in a "frightening" way, becoming, in Selvini's words ([12], p. 79), "exposed to lustful looks, subject to menstruation, intended to be penetrated during sexual intercourse, invaded by the fetus, suckled by the child". According to Brusset [12], there is identification with an already pubescent body, that of the mother or sister, an "identical body" and a "hallucinatory realization of identification". There is confusion, 
then, between her body and that of another person, so alike and yet so different... Actually, Clementine gives way to her new oedipal rival. Her hospitalization enables her to distance herself (physically and psychically) from this climate, and her ongoing treatment keeps her far away from the protagonists of her oedipal conflict. When she mentions her desire not to return home, she says it is "preferable" in order to "avoid conflicts", demonstrating a partial refusal or repression in response to her fear of the oedipal conflict being revived: "I don't want to think that I prefer my father or my mother." If the adoption of anorexic behavior seemed, in the first place, to be an attempt at maintaining her position as a child and her child relationships to the parental objects, we will see how it also addresses a necessity to differentiate herself in order to feel singular in her relationship to her sister, through a subjectivation ${ }^{\mathrm{d}}$ process.

\section{Twinning fantasy within the sisterly relationship Real and fantasized twinning in literature}

For the author Cook-Darzens [13], brotherly links are one of the most significant and lasting relationships in one's life. These links are nowadays recognised as being just as influential as the parent-child relationship. There are two types of twinning: real or fantasized. By "fantasized twinning", we mean the fact of psychically considering oneself as the twin of a brother or sister, whether there is actual biological twinning or not. Not all "simple" brotherly or sisterly relationships lead to these twinning fantasies. We assume that, in the presence of fantasmatical twinning in a sisterly relationship, the psychical mechanisms are similar to those between "real twins". Winestine [14], for example, shows that the lack of differentiation of the Self of each twin, and their reciprocal identification, result in a Self with imprecise outlines. For Houssier [15], the issue of the twin link can be considered from the perspective of two confusions: the first between the sisters themselves, and the second involving the sisters and their mother. Sisterly twinning cancels out the difference between the sexes, but also between generations. Identification with the sister tends to work in mirror image, removing the differences and provoking a real psychical confusion where the Selves of the two subjects seem to get mixed up, split, switched. Access to otherness is therefore disturbed. The almost constant presence of this narcissistic double provides a shield against fear of loss and separation from the primordial love object and makes up for this absence through the investment of a substitution object. When the twin relationship becomes an alienating refuge, avoiding the hallucination of satisfaction, the subject then finds him/ herself in a risky psychic position [16]. Such a tendency towards a lack of differentiation can also be characterized by an unimaginable violence when the archaic intrusion risk ${ }^{\mathrm{e}}$ [17] revives a fear of being devoured by the object, with the other Self swallowing whatever intuition of his/her singularity the subject still has. The twin relationship emerges where the tension between the desire for indistinction and the search for distance from the object (double) is constant [18]. The relationship between the twins and their mother introduces another risk of confusion, as the relationship triangle between the twins and the mother seems to fulfill all roles and all functions. The narcissistic complementarity ${ }^{\mathrm{f}}$ that protects the twin pair against the absence and frustration of the motherly object can convey or reinforce hatred towards the double. Who will be able to best satisfy the primary love object that is the mother? This fear is all the more significant when love and hate echo in the mother and become perceptible in her relationship to her daughters. Through this cleavage (likely not to affect one object only, but to divide the pair into a "good" and a "bad" child), the mother personifies, for Rank [19], the mythical, terrifying fear according to which, for one of the twins to be able to live (and be loved?), the other should be sacrificed. This fear leads the subjects to a need for differentiation, in order for both of them to keep on living together. Houssier [15] points out that the relationship to the other only becomes possible if the other is rendered absent; if not, the alternation between the dyadic union (sister/sister or daughter/ mother) and the triangular relationship (daughters/ mother) brings the risk of repetition and confinement in a closed loop due to the absence of intervention of a third party. If, for Houssier, "by loving too much another like oneself, access to another different from oneself becomes impossible", access to knowledge of one's own self seems just as impossible.

\section{Twinning fantasy and its bursting in the case of clementine}

In the discourse of the parents of Floriane and Clementine, the quality of the sisterly relationship is so strong that a family twinning fantasy is quickly projected onto their two daughters, who seem to be equally invested, but little differentiated. On every picture in a family album brought to a consultation, the two little girls, whose physical resemblance is obvious, are consistently dressed the same way, or swap clothes. When Clementine talks about her sister for the first time in an interview, it is to explain how much the changes she observed when her sister reached puberty shocked her. According to Clementine, the anorexia began right at the moment when her sister went to secondary school and the two young girls were therefore separated. Later, this physical separation will prove to be even more complex, the sisters already having experienced one in primary school: "When Floriane went to secondary school, I felt as if I didn't interest her anymore, she didn't ask my 
opinion on anything". This event creates a fracture between the two sisters, the relationship no longer exists, or, in any case, it is different and divided in two periods, a very distinct before and after. The before is built on the omnipotence of the sister, with all the ambivalence and frustration that implies: "When we were little, we did almost everything together. We had the same friends, and I often felt as if nothing was really mine because I shared it all with her". For Clementine, the after is marked by a huge need for demarcation and individuation. She emphasises the fading of the physical resemblance from childhood and the respective changes of the two sisters since Floriane entered secondary school. Hospitalization accentuates the separation: Clementine talks of her confusion when her best friend becomes closer to her sister: "I don't understand what she is doing. It is as if by being with my sister she is taking a part of me; it seems she's trying to be with me". This fantasy is emphasized by the words of other members of the family: "When we were little, my grand-mother often said, "the girls", as if we were one person." Moreover, Clementine doesn't think about reconnecting with her sister: "I know full well she wouldn't want to see me anyway". She seems motivated by the profound conviction that she can know what her sister desires without having to check with her. Clementine actually projects onto Floriane her own desire not to see her sister and the double fear it could bring about in her: being judged by Floriane and faced (again) with an image of her present self, changed by puberty. The ambivalence resulting from this extreme closeness between the sisters turns to hatred as Clementine sees herself as "the wronged child of the two", now that her "double" not only isn't with her anymore, but is also surrounded by her parents and friends, at a time when Clementine describes herself as very lonely. The sisterly pair is cleaved into the "good" and the "bad" child, and as a result, a fierce rivalry arises in relation to their parents: which one of the two will possess them? Clementine explains: "Before, it was my sister who had everything, even our parents, and then, when I got sick, it was my turn to have them. Floriane was jealous at that time, even though it wasn't my fault - I didn't choose to be sick...". Choice is denied and fate invoked in an attempt to stop feeling guilty that displays a hint of hatred towards her sister, oscillating between a feeling of loss and rivalry. Beyond the school separation reported by Clementine, it is really all about a change that bursts this mirrored relationship. Clementine explains that she can't work out if it is she who has changed, or Floriane, and the distance resulting from the hospitalization is very convenient in her attempt to free herself from her confusion. There is a fantasmatic break-up of the bodies in a separation between pubescent and non-pubescent: "Anyway, even if Floriane wanted to see me, it would only be to know if I have changed". The two girls are now different; the fantasmatic twinning relationship cannot carry on and is therefore broken. We are dealing here with puberty changes, adolescent future, and Clementine, with her child body, may disappoint her narcissistic double, who already began to feel betrayed when her younger sister started her eating restrictions, therefore condemning them to certain separation. "When I was in secondary school, my sister told me things like: 'I can see it coming, if you keep on not eating, you'll end up in hospital!' Stuff like that...". The persecuting dimension of this interiorized voice suggests the magnitude of Clementine's ambivalent conflict: hating her double in an attempt to free herself from such deadly specular influence ${ }^{\mathrm{g}}$, she badly conceals a feeling of abandonment which she unconsciously repeats through the separations caused by her hospitalization. So, physical distance replaces the separation from secondary school and Clementine resolutely maintains the fantasmatic separation of the bodies, refusing to join her sister in puberty. The betrayal is reversed, but the mirroring game remains unchanged and the behaviors are repeated in negative, from normal to pathological. There is a clear boundary between being "similar" to one's sister and being "identical" to her, with all the confusion that can entail. Trapped in very strong identificatory movements towards her sister, Clementine seems to be suffering from a confusion of the Self, switching her childhood memories with her sister's. The metamorphosis of Floriane at puberty led her to adopt, with anorexia nervosa, the most extreme position: a reversed mirrored behavior, in an attempt at any cost to recreate a singularity that she is cruelly lacking. We are now going to see how this acquisition of singularity can only take place after removal from the conflictive family environment and how the nursing framework favors, in this context, the initiation of a subjective elaboration process.

\section{Evolution within the hospitalization framework: towards an entry into puberty}

The admission of Clementine to an institutional setting followed a state of intense undernutrition that led to her hospitalization in the pediatrics unit. The nine months during which Clementine was fed via a feeding tube and confined to her room are reminiscent of the length of a pregnancy; and the feeding tube echoes the umbilical cord, keeping her alive through a psychic holding strongly invested by the nursing team. This period of care serves as a "second, non-forgotten pregnancy", a restoration of the first one. At the beginning of the therapeutic follow-up in the unit, the main questioning of the young girl revolves around her family framework, mainly when she talks about her childhood memories on the farm where she grew up, surrounded by a family within which she felt misunderstood, because deemed too young and immature to have her own ideas and 
opinions. We have already written that in the rural world, "actual physical closeness leads to a psychic closeness and a psychic apparatus that differentiates itself with difficulty, barely able to create something individual, remaining a whole in which the "one" can hardly appear. Some [adolescents] use defense mechanisms of varying degrees of strictness to free themselves from this influence, whereas others remain dependent on the family group without being able to differentiate themselves, subjectivate or access the external world" [20]. Clementine seems to have mixed feelings about the prospect of growing up, and the revitalization of debt and dependency issues becomes important: "When you're a child, as soon as you need something, your parents take care of giving it to you; when you grow up, you have to go and ask for things, and find a way of getting them yourself." For Clementine, adolescent empowerment brings insecurity, as it becomes dangerous to rely on a fallible parental or adult base. During only a few months of follow-up, an emergence of the pubertal can be detected in the new questions posed by the young girl, mainly related to her objectal relationships. Within the unit, Clementine distinguishes between her family relationships and the relationships with the care team: "They are here to help me, not to love me". In this way, she erases, through denial, her desire to be loved as well as the inherent abandonment risk she experienced so painfully in the past. The constraints imposed by her health, which confine her, at the beginning of her hospitalization, to isolation in her room, force solitude upon her, which she complains about. In a constant search for relationships to substitute for her family framework, Clementine explains she always had difficulties making friends: "I always felt different from the other people of my age. We don't have the same interests. I wouldn't say I'm gifted but... well, I certainly feel more mature than they are. Whenever adolescents know each other, they begin to know things and to say things, and I don't like it too much. Some of them can get you in deep water". The investment of her relationships to others demonstrates a fear of otherness ${ }^{\mathrm{h}}$ that denotes a fundamental difficulty "to open up to oneself and to the other without losing oneself" ([9], p. 39), which in this case originates from the experience of family and sisterly indifferentiation. Nevertheless, identification with the other adolescents in the care unit is possible, thus favoring a feeling of belonging to a group: "We are all here because we have problems". Clementine's relationships with the group, especially with the girls, who are "referentreference" figures [8], allow her to integrate quickly, but also to support some changes denoting femininity (haircut, clothes, etc.). At the same time, something akin to the transference ${ }^{\mathrm{i}}$ of the parental object through the pedopsychiatrist emerges, enabling shoring at difficult times. "I don't know what I should say... Things are not going very well, but I don't want to talk to the nurses about it. I only tell Doctor M.” The transferred parental object is conceptualized on the psychoanalyst model, both "internal interlocutor and third party" ([8], p. 206). When it is a real person, present in the environment of the subject, but exogamic ${ }^{j}$, "it is not an object of (pubertal) desire, not a symmetrical double (adolescent narcissism), and not a mere projection of the Ego ${ }^{k}$ and Superego agencies or of the infantile parental imagoes, but instead a psychic construction, both mutable and immutable, made up of these ingredients and having a substrate of flesh" (ibid). The clinical interviews with Clementine and her parents, suggested by the pedopsychiatrist, seem to have involved the mother in an empathetic understanding of her daughter. On the other hand, the refusal to reconnect with her elder sister, as her father requested, only accentuated the decathexis ${ }^{1}$, or even her father's escape from the relationship. As for Floriane, until the end of her sister's hospitalization, she remained a foreign object, excluded from the framework. For Clementine, the deferred work undertaken on her family relationships and her new adolescent status alleviates a fear of repeating her past investment in deficient parental figures, thus enabling a relaxing of her objectal representations. With regard to the distancing of all family influence in this infra-hospital framework, the care enabled her to initiate a process of "subjective elaboration", signifying the way in which the subject "can, according to his/her psychic dynamics, allow him/herself to think, articulate and connect what determines him/ herself in his/her relationships to the other" ([21], p. 49). The therapeutic space of individual follow-up provided Clementine with an environment characterized by listening and composure, which helped strengthen the quality of the transference link. Over the sessions, the initial inhibition of her thinking gave way to the unfolding of a singular discourse, a perception by Clementine of her own person that proved extremely perceptive and curious with regard to her inner world. Being the youngest and frailest patient in the unit, Clementine was invested by the care team as a fragile little girl, but within the walls of the psychologist's office, a very different patient/psychologist/observer relational dynamic emerged, with Clementine being rightly considered as a young adolescent. Transference is « a powerful analogy »([22], p. 221) and the young girl's many questions, as well as her discourse, demonstrated transference dynamics less focused on parental substitution than on "subject supposed to know". Exchanges of looks between Clementine and the observer evolved from distraught looks to an exchange of knowing looks and smiles, evidencing the development of the therapeutic relationship, with the perception of a containing scopic $^{\mathrm{m}}$ alliance in this three-tier relationship. 


\section{Conclusion}

Which benefit (s) from the therapeutic framework can be linked to which impact (s) on the symptom?

Anorexia nervosa therefore gives Clementine, on one hand, the possibility of postponing the revival of the oedipal conflict and, on the other hand, the opportunity to shift her dependence conflict from parental love objects to a food object [5]. Beyond a dependency on the food object, it is a real dependency on the lack of this object that enables her to step back from her family environment. The choice of the anorexic symptom also made possible a physical and psychic distancing from her sister, distancing that was necessary to break a destructive and deadly twinning. The evolution of this young girl, stuck in a process of differentiation at all costs, poses a challenge: how can anorexia nervosa be overcome if its end, marking the beginning of puberty, places it back in an indifferentiation fantasy, this time of two pubescent bodies? What are the therapeutic stakes in these cases of precocious anorexia? In our view, the main stake of this follow-up resides in the restoration of inner solidity that will then allow Clementine to enter the adolescent process without losing herself once again in the sisterly relationship. The benefit of thinking about the individual framework by considering the thinking processes and inner singular reality of the patient, without avoiding the hospitalization framework, also appears essential. The quality of the investment of a group of peers, or of a care team within an environment where "thinking" is no longer marginalized, but allowed and supported, proves to be a good indicator of the solidity of subjectifying processes, and also provides information on the evolution of the subject's representations regarding objectal relations. Thus, the possibility for Clementine to feel that she is singular within dual, triangular or group relationships may thereafter make it possible for the release, or even abandonment, of the symptom not to be experienced as a deconstruction of her subjectivity.

\section{Consent}

Written informed consent was obtained from the patient's parents for publication of this Case Report and any accompanying images. In order to protect privacy of the patient and her family members, all the names have been changed. A copy of the written consent has been seen by the Editorial team.

\section{Endnotes}

${ }^{a}$ For Winnicott, a mother should hold her baby. He calls "holding" the way the mother cares for her newborn, to answer his physiological needs (by speaking, touching, looking...) according to his development. Holding is also the specific way to physically and psychically protect the baby from distressing experiences. b The "Good-enough mother", according to Winnicott, is the behavior a mother adopts when she takes care of her baby, answering his omnipotence. She has knowledge of her baby's sensations, she responds to his needs and she repeats her care over and over. This way the baby will create his own Self.

${ }^{\mathrm{c}}$ According to Freud, the Oedipal promise concerns the child's (or teenager's) unconscious desires to murder his father (her mother for a girl) and love his mother (her father for a girl).

${ }^{\mathrm{d}}$ For psychoanalysis, subjectivation is the act of becoming a subject. A process that occurs throughout a lifetime, with all the psychical changes that take place due to personal experiences (body, history, family, school, social and love life...).

${ }^{\mathrm{e}}$ Archaic intrusion risk is a risk of deconstruction and regression in a child's early stages of development, due to the threatening presence of someone (physical or psychological).

${ }^{\mathrm{f}}$ In psychoanalysis, narcissistic complementarity is about looking for something or someone to complete the faint Self.

geadly specular influence is the phenomenon that occurs when a subject experiences a very bad feeling in relation to a negative image of himself, like looking through a deformed mirror.

${ }^{\mathrm{h}}$ Otherness, for psychoanalysis, consists in recognizing other people in their difference, i.e. different from the Self of the subject.

${ }^{\mathrm{i}}$ In psychoanalysis, transference is a phenomenon characterized by unconscious redirection of feelings from one person to another, particularly the most important persons in childhood (like parents). Throughout the therapeutic process, these feelings are projected onto the psychologist or the psychoanalyst.

${ }^{j}$ Exogamic means to have relations outside of the original group (familial and social).

${ }^{\mathrm{k}}$ In psychoanalysis the terms Ego and Self may be used interchangeably.

${ }^{\mathrm{l}}$ Decathexis means the withdrawal of cathexis, which is defined as the process of investment of mental or emotional energy in a person, object, or idea.

${ }^{\mathrm{m}}$ Scoping is the pleasure of looking, in psychoanalysis theories.

\section{Competing interests}

We, Manon Rivière and Marion Haza, declare that we have no competing interests of any kinds (financial, political, personal, religious, ideological, academic, intellectual, commercial, etc.).

\section{Authors' contributions}

MR has made substantial contributions to conception, data acquisition and analysis of in Clementine's case. MH has been involved in drafting the manuscript and revising it critically for all intellectual content, both theoretical and clinical. Both MR and MH have given final approval of the version to be published and are accountable for all aspects of the work and 
for ensuring that questions related to the accuracy or integrity of any part of the work are appropriately investigated and resolved.

\section{Authors' information}

Manon RIVIËRE: Clinical Psychologist, PhD student in Clinical Psychology, CAPS EA4050, University of Poitiers. Marion HAZA: Clinical Psychologist, President of ARCAD Association, Senior Lecturer, CAPS EA4050, University of Poitiers, Member of the ICLA.

\section{Acknowledgements}

For their various contributions to this article, we would like to thank our patient, Clementine, for giving us this singular case, and the Psychiatric Unit of Children and Teenagers for its hospitality. We would also like to thank our University and specifically the laboratory of Clinical Psychology (CAPS) and the Doctoral School (CCL) for funding the translation of the text, and we are grateful to Lucie Haza and Robert Fletcher for the translation. Finally, thanks to Managing Editor CAPMH Astrid Fidika and the two reviewers of this article for their precious advice.

\section{Author details}

'Maison des Sciences de l'Homme et de la Société, 5, Rue Théodore Lefebvre (Bât. A5), 86000 Poitiers, France. ${ }^{2}$ Université de Poitiers, EA 4050 Laboratoire CAPS, 3, Rue Théodore Lefebvre (Bât. A4), 86000 Poitiers, France.

Received: 11 December 2013 Accepted: 9 June 2014

Published: 11 September 2014

\section{References}

1. Smith C, Steiner H: Psychopathology in Anorexia Nervosa and Depression. J Am Acad Child Adolesc Psychiatry 1992, 31(5):841-843.

2. Winnicott D: Jeu et réalité : L'espace potentiel. Paris: Gallimard; 1971. 1975.

3. Grange-Ségéral E, Aubertel F: Être seul en présence de sa famille: enjeux et impacts de l'adolescence dans la groupalité familiale en thérapie. In Revue de psychothérapie psychanalytique de groupe. 53rd edition. Toulouse: Editions érès; 2009:29-39.

4. Winnicott D: La mère suffisamment bonne. Paris: Payot; 1966. 2006.

5. Recalcati M: Séparation et refus: considérations sur le choix de l'anorexie. Psychanalyse 2010, 18:5-17. Toulouse: Editions érès.

6. Freud S: Deuil et mélancolie. Paris: Payot; 1917. 2011.

7. Kestemberg E: Notule sur la crise de l'adolescence. In Revue française de psychanalyse, 47, 3-4. 47th edition. Paris: PUF; 1980:523-530.

8. Gutton P: "The pubertal, its source and fate" 1998. In Adolescence and Psychoanalysis: The Story and the History. Edited by Ladame F, Perret-Catipovic M. London: Karnac books; 1998:133-148.

9. Corcos M, Lamas C, Pham-Scottez A, Doyen C: L'anorexie mentale, déni et réalités. Paris: Editions Doin; 2008

10. Cahn R: Adolescence et folie. Paris: P.U.F, Le fil rouge; 2004:292.

11. Haza M: Puberté et virginité, l'accès à la sexualité adulte. A propos de Virgin Suicide. In L'adolescente et le cinéma. Edited by Dupont S, Paris H. Toulouse, érès: La vie de l'enfant; 2012:105-114.

12. Brusset B: Psychopathologie de l'anorexie mentale. Paris, Dunod: Psychismes; 2008.

13. Cook-Darzens S: La fratrie, dans I'ombre de l'anorexie mentale. Thérapie Familiale 2009, 30:327-352.

14. Winestine MC: Le jumelage et la différenciation psychologique. In L'enfant dans sa famille. Paris: P.U.F; 1984:111-119.

15. Houssier F: L'enfant jumeau et son devenir. Indifférenciation et subjectivation dans le lien sororal. Topique 2005, 93:91-103.

16. Sourzat M-C: Le motif du jumeau. Topique 1991, 50:43-62.

17. Lacan J: Les complexes familiaux dans la formation de l'individu. Essai d'analyse d'une fonction en psychologie. In Autres écrits, éditions du Seuil. Paris: Editions du Seuil; 2001:23-84.

18. Houssier F: La séduction fraternelle dans la théorie freudienne: de l'enfance à la fin d'adolescence. Dialogue 2004, 164:47-57.

19. Rank O: Don Juan et le double. Paris: Payot; 1932.
20. Haza M, Grolleau E: Clinique itinérante en milieu rural. In Le divan familial. 23rd edition. Paris; 2009:183-196. In Press.

21. Grihom M-J, Laflaquière A: L'élaboration subjective des liens au génogramme chez l'enfant : la tension entre le semblable et le dissemblable et les processus d'analogisation. Bulletin de psychologie 2004, 57:465-478.

22. Neyraut M: Les figures de lírrationnel. Paris: PUF; 1997.

doi:10.1186/1753-2000-8-25

Cite this article as: Rivière and Haza: Melancholy and separation in prepuberty: the choice of anorexia nervosa as a subjectivation attempt. Child and Adolescent Psychiatry and Mental Health 2014 8:25.

\section{Submit your next manuscript to BioMed Central and take full advantage of:}

- Convenient online submission

- Thorough peer review

- No space constraints or color figure charges

- Immediate publication on acceptance

- Inclusion in PubMed, CAS, Scopus and Google Scholar

- Research which is freely available for redistribution

Submit your manuscript at www.biomedcentral.com/submit
C Biomed Central 